\title{
Direct and Indirect Effects of Dissolved Organic Matter Source and Concentration on Denitrification in Northern Florida Rivers
}

\author{
Megan L. Fork ${ }^{1,2 *}$ and James B. Heffernan ${ }^{2}$ \\ ${ }^{1}$ Department of Biological Sciences, Florida International University, 11200 SW 8th St., Miami, \\ Florida 33199, USA; ${ }^{2}$ Present address: Nicholas School of Environment, Duke University, \\ Box 90328, Durham, North Carolina 27708, USA
}

\begin{abstract}
Using a natural gradient of dissolved organic carbon (DOC) source and concentration in rivers of northern Florida, we investigated how terrestriallyderived DOC affects denitrification rates in river sediments. Specifically, we examined if the higher concentrations of DOC in blackwater rivers stimulate denitrification, or whether such terrestriallyderived DOC supports lower denitrification rates because (1) it is less labile than DOC from aquatic primary production; whether (2) terrestrial DOC directly inhibits denitrification via biochemical mechanisms; and/or whether (3) terrestrial DOC indirectly inhibits denitrification via reduced light availability to-and thus DOC exudation byaquatic primary producers. We differentiated among these mechanisms using laboratory denitrification assays that subjected river sediments to factorial amendments of $\mathrm{NO}_{3}{ }^{-}$and dextrose, humic
\end{abstract}

acid dosing, and cross-incubations of sediments and water from different river sources. DOC from terrestrial sources neither depressed nor stimulated denitrification rates, indicating low lability of this DOC but no direct inhibition; humic acid additions similarly did not affect denitrification rates. However, responses to addition of labile $\mathrm{C}$ increased with long-term average DOC concentration, which supports the hypothesis that terrestrial DOC indirectly inhibits denitrification via decreased autochthonous production. Observed and future changes in DOC concentration may therefore reduce the ability of inland waterways to remove reactive nitrogen.

Key words: DOC; light limitation; coupled biogeochemical cycles; nitrogen cycle; primary production; browning; humic substances.
Received 30 May 2013; accepted 25 July 2013

Electronic supplementary material: The online version of this article (doi:10.1007/s10021-013-9705-9) contains supplementary material, which is available to authorized users.

Author Contributions: Both authors have contributed substantially to the conception, data collection and analysis, and have contributed significantly to the writing of the manuscript. Both authors have read and approved the final submitted version of this paper.

*Corresponding author; e-mail: megan.fork@duke.edu

\section{INTRODUCTION}

Dissolved organic carbon (DOC) performs a wide array of roles in aquatic ecosystems (Prairie 2008). Some of the compounds in the DOC pool directly fuel heterotrophic bacterial metabolism (Mulholland 1997; Freeman and others 2001; Evans and others 2005; Cole and others 2006), coupling the cycling of carbon $(\mathrm{C})$ to cycles of nutrients such as nitrogen $(\mathrm{N})$. In addition, biogeochemical processes 
such as photosynthesis, $\mathrm{N}$-fixation, and denitrification tightly couple cycles of $\mathrm{C}$ and $\mathrm{N}$ (Sterner and Elser 2002; Burgin and others 2011; Schlesinger and others 2011). In addition to these direct effects, DOC may affect oxygen and $\mathrm{N}$ concentrations indirectly through its effects on the temperature and light regimes, which are major physical controls on photosynthesis and respiration in surface waters (Evans and others 2005).

Understanding how DOC affects stream nutrient processing depends on understanding of the diverse effects of DOC in aquatic ecosystems as well as their interactions. Recently observed widespread increases in DOC concentrations of inland surface waters (or "browning"; Worrall and others 2004; Evans and others 2005; Roulet and Moore 2006; Hruška and others 2009) may therefore have complex and unforeseen consequences for the biogeochemical function of inland waters, because the possible effects of browning on nutrient cycles are many, and they may interact and oppose one another. To predict how browning may affect the $\mathrm{N}$ cycle, it is necessary to consider interactions between the direct metabolic effects of DOC as well as any indirect effects that result from changes in the physical environment.

One link between the $\mathrm{C}$ and $\mathrm{N}$ cycles is denitrification, a heterotrophic pathway by which nitrate $\left(\mathrm{NO}_{3}{ }^{-}\right)$is reduced to di-nitrogen gas $\left(\mathrm{N}_{2}\right.$; if the process runs to completion), coupled to the oxidation of organic matter $(\mathrm{OM})$ in low-oxygen conditions (Canfield and others 2010). This process is an important pathway for the removal of reactive $\mathrm{N}$, and occurs both in uplands and during transport through river networks (Alexander and others 2000; Seitzinger and others 2006). Denitrification therefore has the potential to reduce the effects of human additions of reactive $\mathrm{N}$ to ecosystems, which include eutrophication of freshwater habitats and hypoxic "dead zones" in coastal oceans (Turner and Rabalais 1991; Vitousek and others 1997; Galloway and others 2003). The degree to which denitrification is able to remove reactive $\mathrm{N}$ during transport through aquatic ecosystems may depend on the DOC regimes of these systems.

OM not only fuels denitrification directly (Pfenning and McMahon 1997; Bernhardt and Likens 2002; Inwood and others 2007), but also indirectly by stimulating aerobic respiration, which enhances denitrification rates by increasing the anoxic volume in soils and sediments. Considered in isolation, these mechanisms predict higher denitrification rates in rivers with higher concentrations of DOC (Figure $1-\mathrm{H} 0$ ). The actual consequences of DOC for denitrification, however, depend on the character of the DOC, which is strongly influenced by source (Piña-Ochoa and Álvarez-Cobelas 2006; Inwood and others 2007; Taylor and Townsend 2010). Both nutrient stoichiometry and structural complexity influence bioavailability of DOC (Sun and others 1997; Barnes and others 2012). Terrestrially-derived DOC is generally much more recalcitrant than that exuded by aquatic primary producers (McKnight and Bencala 1990; Sierra and others 1997; Thorp and Delong 2002; Stedmon and others 2003), because organic compounds that give physical support to terrestrial plants tend to be more structurally-complex and lower in nutrient content than $\mathrm{OM}$ derived from aquatic primary producers (Cebrian 1999; Sterner and Elser 2002; Thorp and Delong 2002) and because much of the labile DOC produced in terrestrial soils is consumed by soil heterotrophs (McDowell and Likens 1988) before reaching waterways. A given concentration of terrestrially-derived DOC is therefore likely to support less denitrification than an equivalent amount derived from in situ production by aquatic vegetation (Figure $1-\mathrm{Hl}$ ).

In addition to being less labile, terrestrial DOC may inhibit denitrification in aquatic systems via both direct and indirect mechanisms. First, functional groups such as phenolics, which are more concentrated in DOC from terrestrial than aquatic sources, may directly suppress the activity of denitrifiers (Figure 1-H2; Dodla and others 2008). Second, light-absorbent aromatic compounds such as tannic and humic acids may reduce photosynthesis and thus production of labile exudates by aquatic primary producers (Meyer 1990). Because the release of OM by benthic algae and macrophyte roots can stimulate denitrification (Arango and others 2007; Heffernan and Cohen 2010; Heffernan and Fisher 2012; Lin and others 2002), high concentrations of chromophoric dissolved OM (CDOM) in aquatic ecosystems may indirectly suppress denitrification by reducing the light that fuels these autochthonous OM inputs (Figure $1-\mathrm{H} 3$ ).

The importance of light as a potential control on denitrification in stream ecosystems is understudied because most research on stream $\mathrm{N}$ cycling is conducted in small streams with closed canopies (for example, Peterson and others 2001; Mulholland and others 2008), leaving processes in larger rivers less well understood (Ensign and Doyle 2006; Tank and others 2008). In larger channels as well as lakes and wetlands, reduced shade by riparian vegetation and higher light availability can promote photodegradation of recalcitrant DOC to more labile compounds (Moran and Zepp 1997). Perhaps more importantly, higher light will fuel higher benthic primary production (Lamberti and 


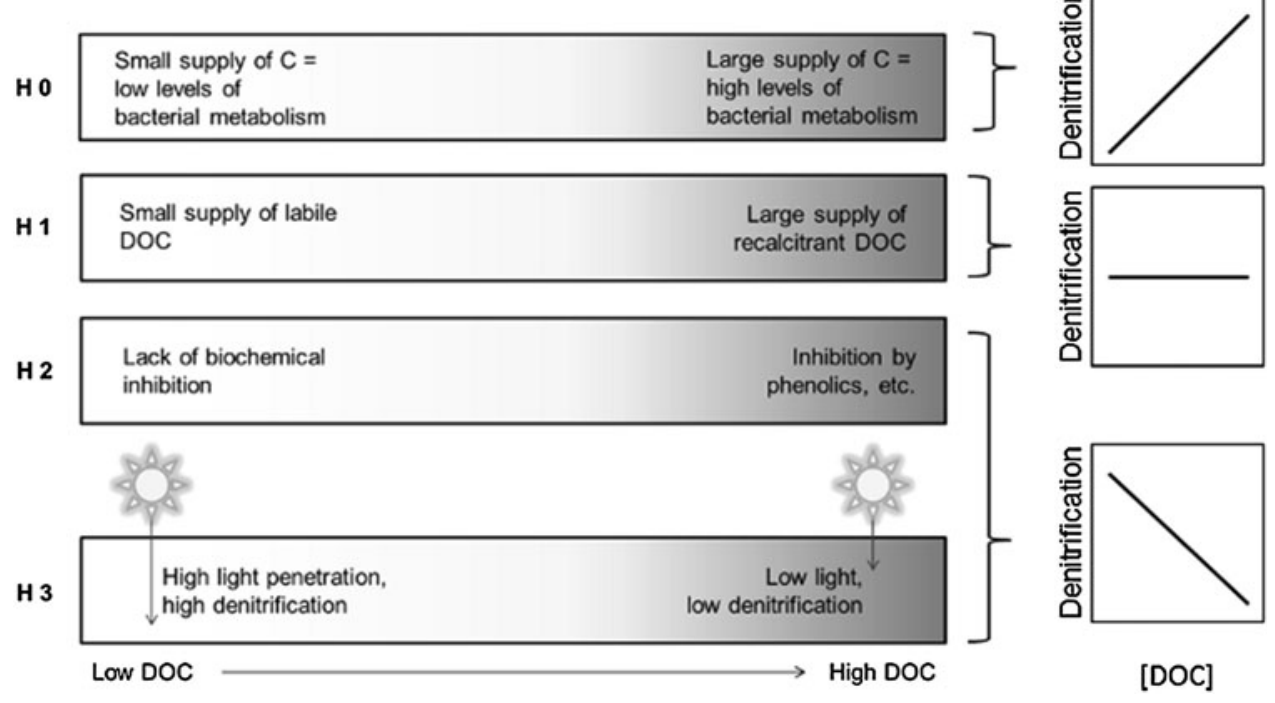

Figure 1. Hypotheses about the effects of terrestrially-derived DOC on denitrification rates. Blackwater rivers have high concentrations of terrestrial DOC, which may stimulate denitrification rates [H0]. However, the terrestrially-derived DOC of blackwater rivers may support similar rates of denitrification as spring rivers, even though springs have much lower DOC, because blackwater DOC is less labile to both denitrifiers and aerobic consumers [H1]. Blackwater rivers may support lower rates of denitrification as compared to spring fed rivers because blackwater DOC is directly inhibitory to denitrifying bacteria [H2] and/or may limit light to aquatic primary producers, indirectly limiting denitrification by decreasing production of labile OM [H3]. Along a gradient from spring to blackwater, DOC concentrations increase, leading to higher denitrification rates if $\mathrm{HO}$ is true, little change if $\mathrm{Hl}$ is true, or lower rates if $\mathrm{H} 2$ and/or $\mathrm{H} 3$ are true.

Steinman 1997), and thus greater exudation of labile OM into sediments by aquatic plants. In rivers, the importance of in situ primary production to denitrification may increase with channel size (Heffernan and others 2010), up to a point. In lacustrine pelagic zones, very large rivers, and highly eutrophic systems, proliferation of phytoplankton (Vannote and others 1980) increases turbidity and limits light penetration (Julian and others 2008), thus limiting benthic primary production (Vadeboncoeur and others 2003). In addition, high concentrations of CDOM can limit the penetration of light in the water column, thereby further controlling benthic primary production.

Streams and rivers in northern and central Florida span a wide range of DOC concentrations, from entirely spring-fed channels with relatively low DOC and highly productive benthic plant communities to blackwater systems with high concentrations of DOC derived mainly from breakdown of terrestrial vegetation. Downstream of confluences between these distinct river types are sites of intermediate DOC concentration. We used sediments from sites arrayed along this gradient of $\mathrm{C}$ source and concentration, and subjected them to a suite of complementary experiments, which allowed us to distinguish among mechanisms by which high concentrations of terrestrially- derived DOC in BW rivers affect denitrification rates (Figure 1). The hypotheses we tested were:

Ho Blackwater rivers' higher concentrations of DOC support higher rates of denitrification because they provide more fuel for denitrifying bacteria.

H1 Terrestrial DOC is less labile than exudates from autochthonous production, meaning the DOC present in blackwater systems is not useful fuel for denitrifiers.

H2 Phenolic compounds present in blackwater directly inhibit the functions of denitrifying bacteria.

H3 Absorption of light by blackwater DOC reduces benthic primary production, which indirectly inhibits denitrification because of the lack of labile exudates to fuel denitrifier metabolism.

\section{MethodS}

We identified study sites in north central Florida that encompassed a wide gradient of DOC concentrations. Water and sediment samples from these sites were used to perform denitrification assays to evaluate differences in the severity of $\mathrm{C}$ and $\mathrm{N}$ limitation of denitrification rates. We used 
DOC dosing and source water substitution experiments to determine if blackwater DOC directly stimulated or inhibited denitrification rates.

\section{Site Selection and Description}

Rivers in northern Florida, USA include spring-fed and blackwater rivers. Spring-fed rivers have very clear water, are hydrologically, chemically, and thermally stable, and support highly productive aquatic plant communities (Odum 1957a). Substrates are typically mixtures of sand and silt with varying concentrations of benthic OM; areas of bare limestone bedrock also occur (especially near spring heads). Total organic C (TOC) concentrations near spring heads are among the lowest in the world, typically below practical detection limits of 0.02 to $0.12 \mathrm{mg} \mathrm{C} \mathrm{L}^{-1}$ (EPA method 415.3, Scott and others 2004; Duarte and others 2010). Nonetheless, longterm and high-resolution mass balance indicates that these systems support high rates of denitrification, up to $1.5 \mathrm{~g} \mathrm{~N} \mathrm{~m}^{-2}$ day $^{-1}$ (Heffernan and Cohen 2010; Heffernan and others 2010). In contrast, blackwater rivers are characterized by low gradients and tannic, dark-stained water that attenuates light and allows minimal benthic primary production (Meyer 1990). The dark-colored water results from high concentrations of fulvic and tannic acids, organic C compounds derived from the decomposition of terrestrial vegetation in the wetlands, where these rivers originate (Meyer 1990; Sabater and others 1993). In northern Florida, these blackwater rivers are primarily sand-bottomed. Both spring and blackwater rivers in this region tend to have low turbidity (personal observation). These distinct river types and the intermediate conditions created by their mixing (Bledsoe and Phlips 2000) provide a natural environmental gradient of DOC.

Using satellite images (Google Earth-earth.google.com) and data from the EPA STORET (www. epa.gov/storet/) database, we identified 20 study sites representing an environmental gradient of DOC concentration in north and central Florida, USA (Figure 2). Sites were located in Florida's Central Lake and Ocala Uplift physiographic districts, generally characterized by sandhill and sand pine scrub communities, and mixed hardwood, pine flatwood, and sandhill communities, respectively (Myers and Ewel 1990). Precipitation regimes in north and central Florida are moderately seasonal with higher rates in summer. Temperature ranges from a summer mean of $27-30^{\circ} \mathrm{C}$ to a winter mean of about $15-17^{\circ} \mathrm{C}$ (Myers and Ewel 1990).

We used data from the St. John's, Suwannee River, and Southwest Florida Water Management Districts, and EPA STORET database to describe

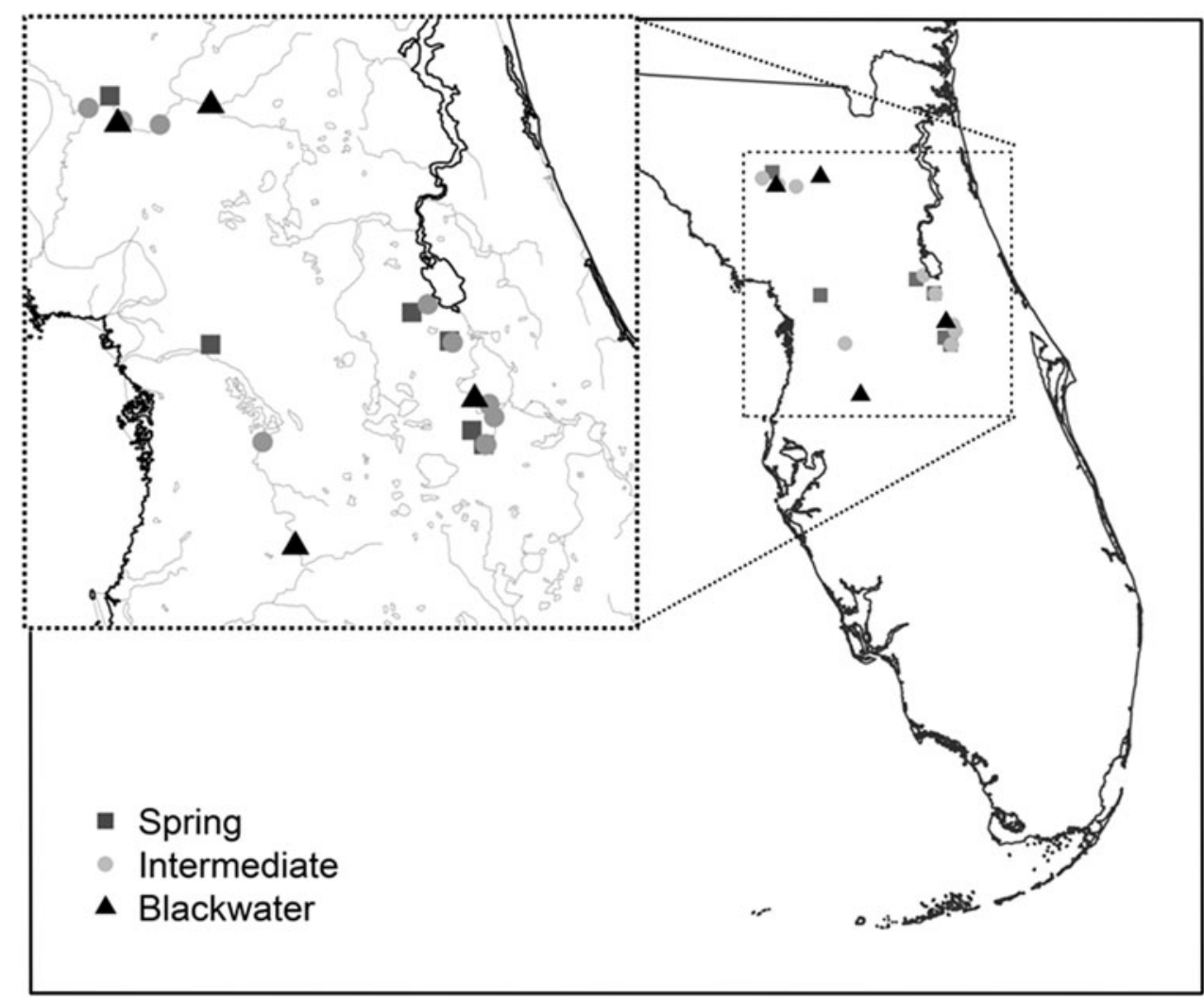

Figure 2. Map of sampling sites by category. Major water bodies (gray) are from U.S. National Wild $\delta$ Scenic Rivers System GIS (www.rivers.gov). 
long-term means of TOC $\left(\mathrm{TOC}_{\mathrm{avg}}\right)$ and other parameters for each study site. TOC was used as a proxy for DOC, because DOC data were less prevalent in the databases, and where good records of both existed, TOC and DOC showed good agreement. For intermediate and blackwater categories, we used only sites with available data that spanned multiple seasons for at least 2 years between 2000 and 2011 to calculate the long term means. For spring sites, the criterion for data that spanned all seasons was relaxed because of lower availability of TOC data for springs, and the fact that these systems tend to exhibit quite stable discharge and water chemistry among seasons (Odum 1957b). These 20 sites made up an environmental gradient of $\mathrm{TOC}_{\mathrm{avg}}$ concentration that ranged from 0.2 to $42 \mathrm{mg} \mathrm{C} \mathrm{l}^{-1}$.

We examined relationships among TOC $_{\text {avg }}$, longterm $\mathrm{NO}_{3}{ }^{-}\left(\mathrm{NO}_{3}{ }^{-}\right.$avg), mean water color (measured by platinum-cobalt colorimetry and obtained from EPA STORET database), coefficient of variation of long-term discharge (that is, hydrologic variability), and water column chlorophyll $a(\mathrm{chl}-a)$ to assess how other characteristics varied along our TOC gradient. In addition, we used dissolved oxygen (DO) measurements from the EPA STORET database to determine how DO concentration changed over the course of an average day. These records include a timestamp, and are collected exclusively during daylight hours. We regressed DO concentration against time of day for our sites with at least 22 measurements having a time range of at least $4 \mathrm{~h}$ of daylight. The slope of the relationship between DO concentration and time of day $(\Delta \mathrm{DO})$ acted as a proxy for average net primary productivity (Mulholland and others 2005). We also measured sediment OM content (SOM) and assessed its co-variation with $\mathrm{TOC}_{\mathrm{avg}}$ along the environmental gradient. $\mathrm{TOC}_{\mathrm{avg}}$ and $\mathrm{NO}_{3}{ }^{-}$avg data were compared with instantaneous DOC ( DOC $_{\text {inst }}$ ) and $\mathrm{NO}_{3}{ }^{-}\left(\mathrm{NO}_{3}{ }^{-}\right.$inst $)$concentrations on the day of sediment and water sampling to assess deviations from historic means at the time of sampling.

Some analyses required that sites be categorized as blackwater, spring, or intermediate on the basis of $\mathrm{TOC}_{\mathrm{avg}}$ and analysis of major confluences upstream of site locations. Sites located downstream of a confluence between a spring and blackwater stream were labeled "intermediate," whereas only sites without major visible inputs (as assessed by publicly available aerial images-earth.google.com) of another type were categorized as "spring" or "blackwater". Because site categories were assigned on the basis of both upstream inputs and $\mathrm{TOC}_{\mathrm{avg}}$, site categories do not always correspond exactly to the TOC gradient (for example, Cow Creek, a blackwater site, has a slightly lower $\mathrm{TOC}_{\mathrm{avg}}$ than the Withlacoochee River at Hwy 48, an intermediate site).

\section{Field Collections and Water Chemistry Analyses}

From each site, we collected five $2 \mathrm{~kg}$ replicates of the top $5 \mathrm{~cm}$ of benthic sediment, the stratum in which $90 \%$ of benthic denitrification occurs (Inwood and others 2007). Sediment samples were stored on ice until returned to the laboratory. We also collected $\sim 40$ l of river water (for treatment solutions) with a peristaltic pump and $0.45 \mu \mathrm{m}$ inline filter, reserving $250 \mathrm{ml}$ of filtered water for laboratory analysis of $\mathrm{DOC}, \mathrm{NO}_{3}{ }^{-}$/nitrite, ammonium, and soluble reactive phosphorus (SRP). Water samples for nutrient analysis were stored on ice during transport, and frozen immediately upon return to the lab. Nutrient analyses were performed in the Southeast Environmental Research Center (SERC) Nutrient Analysis Laboratory by flow injection analysis using an ALPKEM RFA 300 autoanalyzer (Alpkem Corp., Clackamas, OR). Standard U.S. EPA methods (U.S. EPA 1993) were used to measure concentrations of $\mathrm{NO}_{3}{ }^{-}$/nitrite (method 353.2), SRP (method 365.1), and ammonium (method 350.1). Concentration of DOC was measured by high temperature combustion using a Shimadzu TOC-5000 (Shimadzu Corp., Kyoto, Japan), according to USGS method 5310B. A YSI 556 Sonde (YSI Inc., Yellow Springs, $\mathrm{OH}$ ) equipped with an optical DO probe was used to measure DO, $\mathrm{pH}$, specific conductivity, and water temperature at the time of sediment sampling.

Upon return to the laboratory, sediments were stored at $4^{\circ} \mathrm{C}$ until assays were performed. Approximately $12 \mathrm{~h}$ before experiments, sediments were brought to room temperature to allow microbial communities to acclimatize and regain activity before analysis (Herrman and others 2008), and sediments were homogenized in collection bags in the morning before being split for the denitrification assay. All denitrification assays were performed within 6 days of sediment collection.

\section{Denitrification Experiments}

In this study, we performed three different denitrification assay experiments: (1) humic acid additions, (2) water source manipulations, and (3) denitrification limitation assays. Each experiment assessed distinct predictions that follow from alternative hypotheses ( $\mathrm{HO}$ through $\mathrm{H} 3$ ), and was conducted using similar methodology to measure denitrification rate as the response variable (see below).

Humic acid additions, the first of our experiments, addressed possible direct inhibitory effects 
of DOC concentrations outside of the range of DOC concentrations observed in the field, and were conducted using sediments and water from three spring-fed rivers that varied in $\mathrm{NO}_{3}{ }^{-}$concentration [Manatee ("high", $\mathrm{NO}_{3}{ }^{-}$inst $=1.84 \mathrm{mg} \mathrm{l}^{-1}$ ], Ichetucknee ("medium", $\mathrm{NO}_{3}{ }^{-}$inst $=0.50 \mathrm{mg} \mathrm{l}^{-1}$ ), and Alexander ("low", $\mathrm{NO}_{3}{ }^{-}$inst $=0.002 \mathrm{mg} \mathrm{l}^{-1}$ )]. We used Pahokee Peat Humic Acid Standard (International Humic Substances Society catalog number $1 \mathrm{~S} 103 \mathrm{H}$ ) to enrich water from each spring-fed river with high concentrations of humic acids. Treatment solutions consisted of unamended site water as a control and humic acid at concentrations of $50 \mathrm{mg} \mathrm{C}^{-1}$ (similar to the highest DOC concentration observed in the field) and $150 \mathrm{mg} \mathrm{l}^{-1}$ (approximately triple the highest observed DOC). If blackwater DOC stimulates denitrification by fueling bacterial metabolism [HO], we should expect higher rates in sediments incubated with higher humic acid concentrations. If blackwater DOC was simply less labile than autochthonous DOC [HI], dosing sediments with high concentrations of humic acid should cause negligible stimulation of denitrification rates. Direct biochemical inhibition of denitrification by blackwater DOC [H2] would result in depressed denitrification rates for sediments incubated with high doses of standardized humic acid relative to source water control.

We used water substitutions to assess whether blackwater DOC stimulates or inhibits denitrification and whether spring DOC stimulates denitrification in sediments from blackwater rivers. In these experiments, we incubated all sediments with water from spring and blackwater rivers, with the native water serving as control (that is, blackwater sediments incubated with water collected at the same blackwater site). Sediments collected from intermediate points along the gradient were incubated with both spring (S) and blackwater (BW), and also were subjected to a control treatment with native water. These substitution incubations allowed us to assess lability and direct inhibition by blackwater DOC as mechanisms responsible for limiting denitrification rates in each of these types of rivers. If the DOC in blackwater rivers supports higher rates of denitrification than low DOC waters [HO], we should see an increase in rates for spring sediments incubated with $\mathrm{BW}$ and a decrease in rates for sediments from blackwater rivers incubated with $\mathrm{S}$ water. If BW DOC is simply less labile than S DOC $[\mathrm{Hl}]$, spring and intermediate sediments treated with BW should show negligible change in denitrification rates, while sediments from blackwater rivers should show increased rates when incubated with S water. If blackwater DOC is directly inhibitory to the metabolisms of denitrifying bacteria, incubating sediments with BW should depress denitrification rates [H2].

To determine how limitation by $\mathrm{C}$ and $\mathrm{N}$ change along the environmental DOC gradient, we used factorial denitrification limitation assays. Treatment solutions for these experiments used ambient local river water collected on the day of sampling, to which we added dextrose as a highly labile source of $\mathrm{C}$ and/or $\mathrm{NaNO}_{3}{ }^{-}$as a source of $\mathrm{NO}_{3}{ }^{-}$. The factorial amendment assays consisted of four treatments: Control (0; unamended river water), $\mathrm{NO}_{3}{ }^{-}(\mathrm{N}$; river water with additional $14 \mathrm{mg}-\mathrm{N} \mathrm{I}^{-1} \mathrm{NO}_{3}{ }^{-}$added), $\mathrm{C}$ (river water with additional $12 \mathrm{mg}-\mathrm{C} \mathrm{l}^{-1}$ dextrose added), and $\mathrm{C}-\mathrm{NO}_{3}{ }^{-}(\mathrm{CN}$; river water with addi-

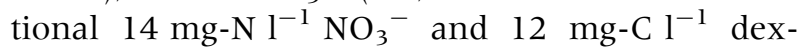
trose). This experiment allowed us to test for indirect inhibition of denitrification via reduced availability of labile C [H3]. Because microbial extracellular enzymes persist in aquatic sediments and have the ability to act on multiple compounds (Münster and De Haan 1998), it is unlikely that lags in DOC processing associated with acclimation of the bacterial community to new $C$ sources significantly affected our analyses. Indirect inhibition by terrestrial DOC would cause an increase in severity of $C$ limitation of denitrification at sites with higher concentrations of terrestrially-derived DOC, because they more acutely attenuate light and inhibit autochthonous production of labile organic compounds.

\section{Denitrification Assays}

For each assay, we added $\sim 100 \mathrm{~g}$ of wet, homogenized sediment to $300 \mathrm{ml}$ BOD bottles, or $\sim 30 \mathrm{~g}$ of sediment to $60 \mathrm{ml}$ BOD bottles, excluding particles too large to fit into the neck of the bottle. For each sampling site, two complete sets of treatments were constructed, with one set measured at time zero (T0) and one set measured after $\sim 6 \mathrm{~h}$ of incubation (T6). Treatment solutions were added at room temperature using a siphon to minimize contact with the atmosphere, and bottles were overfilled so that air was excluded. Solutions were not deoxygenated before incubation experiments. We stoppered bottles and inverted them several times to remove any air pockets from the sediment. Bottles were then partially refilled from the bottom of the water layer, just above the sediment, to remove bubbles, and were incubated with zero headspace. During incubation, bottles were kept in the dark and inverted once per hour to avoid diffusion limitation of $\mathrm{NO}_{3}{ }^{-}$supply to the sediment.

We used membrane inlet mass spectrometry (MIMS) to measure dissolved $\mathrm{N}_{2}$ concentrations in 
the water layer of sediment incubations (Kana and others 1994). MIMS measures dissolved gases directly from water samples, avoiding artefacts associated with the acetylene block technique for conducting denitrification assays (Groffman and others 2006). To reduce $\mathrm{O}_{2}$ interference with $\mathrm{N}_{2}$ measurements, we used an in-line copper reduction column, heated to $600^{\circ} \mathrm{C}$, to remove $\mathrm{O}_{2}$ from samples before measurement (Eyre and others 2002). Standards for $\mathrm{N}_{2}$ concentration consisted of humidatmosphere-equilibrated deionized water in three $1 \mathrm{l}$ spherical vessels, incubated with stirring in highprecision water baths $\left( \pm 0.01^{\circ} \mathrm{C}\right)$ at $10.0,17.0$, and $24.0^{\circ} \mathrm{C}$ for at least $24 \mathrm{~h}$ prior to analysis (Heffernan and others 2012). $\mathrm{N}_{2}$ gas solubility formulas from Hamme and Emerson (2004) were used to calculate $\mathrm{N}_{2}$ concentrations in each standard according to its temperature. During sampling with MIMS, signal strength at each mass was recorded every $5 \mathrm{~s}$, and signal values for samples and standards were determined as the mean value of measurements for the first stable full minute of measurements. A standard curve was run every 4-6 samples to account for instrument drift, and we applied interpolated parameter values to estimate gas concentrations in each sample (Heffernan and others 2012).

T0 measurements were made immediately by directly sampling supernatant water in the BOD bottles using the MIMS intake. These measurements were then subtracted from the T6 measurements to determine the change in $\mathrm{N}_{2}$ concentration over the incubation period. Measurements for T0 and T6 could not be taken from the same bottle because of potential contamination by atmospheric $\mathrm{N}_{2}$ during T0 sampling.

Following $\mathrm{N}_{2}$ measurement, subsamples of sediment were dried to constant mass and SOM content determined as loss on ignition. Individual location measurements of SOM ranged from 0.1 to $85 \%$ and were highly variable within sites, whereas site-level means ranged from 1 to $79 \%$ with an overall mean of $17 \%$ among all sites. We calculated organic sediment mass using the SOM content and dry sediment mass for each T6 sample. We divided the difference in $\mathrm{N}_{2}$ gas concentration for each pair by incubation time and by organic sediment mass to determine SOM-corrected denitrification rates $\left[\mu \mathrm{g} \mathrm{N}\left(\mathrm{g} \mathrm{SOM}^{-1}\right) \mathrm{h}^{-1}\right.$ ].

\section{Statistical Methods}

We used Pearson's correlation coefficients and simple linear regression to assess co-variation of parameters along the environmental long-term TOC gradient. We also examined the effects of both
$\mathrm{TOC}_{\mathrm{avg}}$ and hydrologic variability on log-transformed denitrification rates among sites using simple linear regression.

We assessed the influence of log-transformed SOM content on log-transformed denitrification potential (that is, rates measured in $\mathrm{CN}$ treatment) using simple linear regression. Before analysis, we omitted one data point with Cook's distance $>1$. Because SOM exerted strong control on the denitrification rate, we analyzed treatment effects from humic acid dosing, source water substitution, and limitation assays based on SOM-corrected rates $\left[\mu \mathrm{g} \mathrm{N}\left(\mathrm{g} \mathrm{SOM}^{-1}\right) \mathrm{h}^{-1}\right]$.

We used two-way ANOVA to compare the effects of factorial $\mathrm{C}$ and $\mathrm{N}$ amendments within each site, using a Box-Cox transformation of rates prior to analysis. The effect of humic acid dosing on logtransformed denitrification rates was also assessed using ANOVA. Non-parametric ANOVA on the ranked denitrification rates was used to determine whether water substitution had a significant effect on denitrification rate. We verified conclusions by using Welch's $t$ test to compare the N-replete treatments for $\mathrm{S}$ and BW substitutions. When significant differences in treatment effects were detected, we used Tukey's HSD to identify distinct means.

To compare how $\mathrm{C}$ and $\mathrm{N}$ limitation of denitrification rates changed along the TOC gradient, we calculated response ratios (RRs) of the rates measured in different treatments $\left[\mathrm{N}\right.$ :control $\left(\mathrm{RR}_{\mathrm{N}: 0}\right)$, $\mathrm{C}$ :control $\left(\mathrm{RR}_{\mathrm{C}: 0}\right), \mathrm{CN}: \mathrm{C} \quad\left(\mathrm{RR}_{\mathrm{CN}: \mathrm{C}}\right)$, and $\mathrm{CN}: \mathrm{N}$ $\left.\left(\mathrm{RR}_{\mathrm{CN}: \mathrm{N}}\right)\right]$, then regressed these ratios against TO$\mathrm{C}_{\mathrm{avg}}$ (for $\mathrm{RR}_{\mathrm{CN}: \mathrm{N}}$ and $\mathrm{RR}_{\mathrm{C}: 0}$ ) or $\mathrm{NO}_{3}{ }^{-}$avg (for $\mathrm{RR}_{\mathrm{CN}: \mathrm{C}}$ and $\left.R R_{N: 0}\right)$. Negative values of the RR were omitted prior to log-transformation (two negative values removed from each of $\mathrm{RR}_{\mathrm{C}: 0}$ and $\mathrm{RR}_{\mathrm{CN}: \mathrm{C}}$ ).

We used R version 2.11.1 (R Development Core Team 2012) with the package "MASS" (Venables and Ripley 2002) to perform all statistical analyses.

\section{RESUlts}

Denitrification rates measured in the control treatment (hereafter, "ambient rates") ranged from $0.001 \mu \mathrm{g} \mathrm{N} \mathrm{g} \mathrm{sed}^{-1} \mathrm{~h}^{-1}$ (Santa Fe River, "SF121") to $3.615 \mu \mathrm{g} \mathrm{N} \mathrm{g} \mathrm{sed}^{-1} \mathrm{~h}^{-1}$ (Wekiwa Springs run, "Weku"), with a mean of $0.517 \mu \mathrm{g} \mathrm{N} \mathrm{g} \mathrm{sed}{ }^{-1} \mathrm{~h}^{-1}$. Potential denitrification rates (rates measured in $\mathrm{CN}$ treatment) ranged from $0.107 \mu \mathrm{g} \mathrm{N} \mathrm{g} \mathrm{sed}^{-1} \mathrm{~h}^{-1}$ (Withlacoochee River, "WithRiv") to $6.966 \mu \mathrm{g}$ $\mathrm{N} \mathrm{g} \mathrm{sed}{ }^{-1} \mathrm{~h}^{-1}$ (Wekiva River, "Wekd"), with a mean of $2.042 \mu \mathrm{g} \mathrm{N} \mathrm{g} \mathrm{sed}^{-1} \mathrm{~h}^{-1}$ (Appendix 1 in Supplementary material).

Water color and $\mathrm{TOC}_{\mathrm{avg}}$ were strongly and positively correlated (adjusted $r^{2}=0.87, P<0.001$ ) 
among these study systems. Although hydrologic variability was strongly positively related to $\mathrm{TOC}_{\mathrm{avg}}$ (adjusted $r^{2}=0.82, P<0.001$ ), $\mathrm{NO}_{3}{ }^{-}$co-varied only weakly with $\mathrm{TOC}_{\text {avg }}\left(\mathrm{NO}_{3}{ }^{-}\right.$avg: $P=0.13, \mathrm{NO}_{3}{ }^{-}$inst: $P=0.10)$. Chl- $a$ (a metric of primary production in the water column) was positively correlated with TOC $_{\text {avg }}$ (adjusted $r^{2}=0.16, P<0.001$ ), but $\Delta \mathrm{DO}$ (a proxy for ecosystem net primary production; Mulholland and others 2005) had a negative relationship with TOC $_{\text {avg }}$ (adjusted $r^{2}=0.32, P<0.001$ ). DOCinst and $\mathrm{NO}^{-}{ }^{-}$inst correlated reasonably strongly with their respective long-term average metrics: TOC $_{\text {avg }}$ (adjusted $\left.r^{2}=0.76, P<0.001\right)$ and $\mathrm{NO}_{3}{ }^{-}$avg (adjusted $\left.r^{2}=0.60, P<0.001\right)$.

SOM was positively correlated with potential denitrification rate (rate measured in $\mathrm{CN}$ treatment), explaining $65 \%$ of its variation $(P<0.001)$. Similar relationships, though weaker, existed between SOM and denitrification rates measured in other treatments, particularly when negative rates were omitted from the analysis (adj. $r_{\text {control }}^{2}=0.43 ;$ adj. $r_{\text {Conly }}^{2}=0.38$; adj. $r_{\text {Nonly }}^{2}=0.52$ ).

Denitrification assays showed strong evidence for $\mathrm{NO}_{3}{ }^{-}$limitation in 16 of 20 sites (Appendix 1 in Supplementary material), including the spring-fed Ichetucknee River (Figure 3). None of the sites showed evidence of $\mathrm{C}$ limitation alone, but two sites showed a significant interaction between $\mathrm{C}$ and $\mathrm{NO}_{3}{ }^{-}$amendments. In the blackwater site Cow Creek, the effects of the CN treatment were approximately additive of the effects of either $\mathrm{C}$ or $\mathrm{N}$ alone, indicating co-limitation of the denitrifying bacterial community by both labile $\mathrm{C}$ and $\mathrm{NO}_{3}{ }^{-}$ (Figure 3).

Water substitution had no significant effect on denitrification rates for any combination of sediment and water source (for blackwater sediments, $P=0.65$; intermediate sediments, $P=0.60$; spring
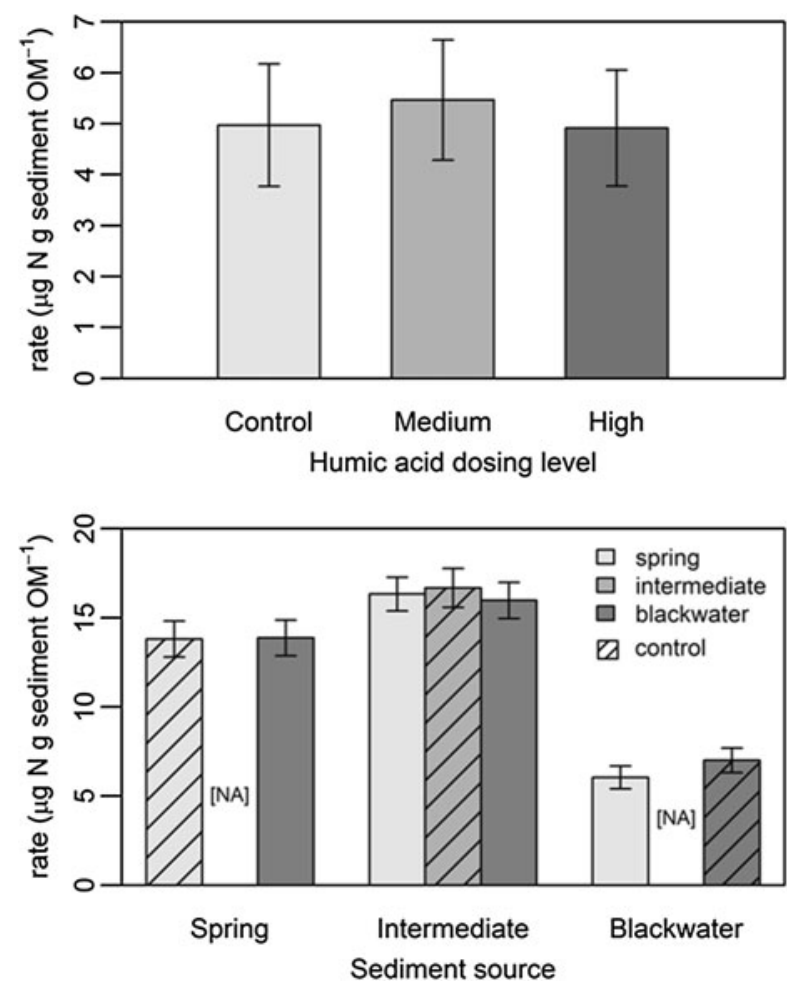

Fig. 4. SOM-corrected denitrification rates versus humic acid dosing level (top). Error bars show one standard error. Dosing of humic acid at concentrations of $50 \mathrm{mg} \mathrm{C} \mathrm{l}^{-1}$ (Medium) and $150 \mathrm{mg} \mathrm{C}^{-1}$ (High) neither significantly stimulated nor depressed denitrification rates as compared to the control (background) DOC levels $(P=0.96)$. SOM-corrected denitrification rates for $\mathrm{N}$-replete water substitution experiments by sediment source (bottom). Colors of bars represent water source; water from same source as sediment (controls) are shown by hashed bars. Error bars show one standard deviation. Water substitution did not produce significantly different denitrification rates within any of the sediment source groups (blackwater sediments, $P=0.65$; intermediate sediments, $P=0.60$; spring sediments, $P=0.53)$.
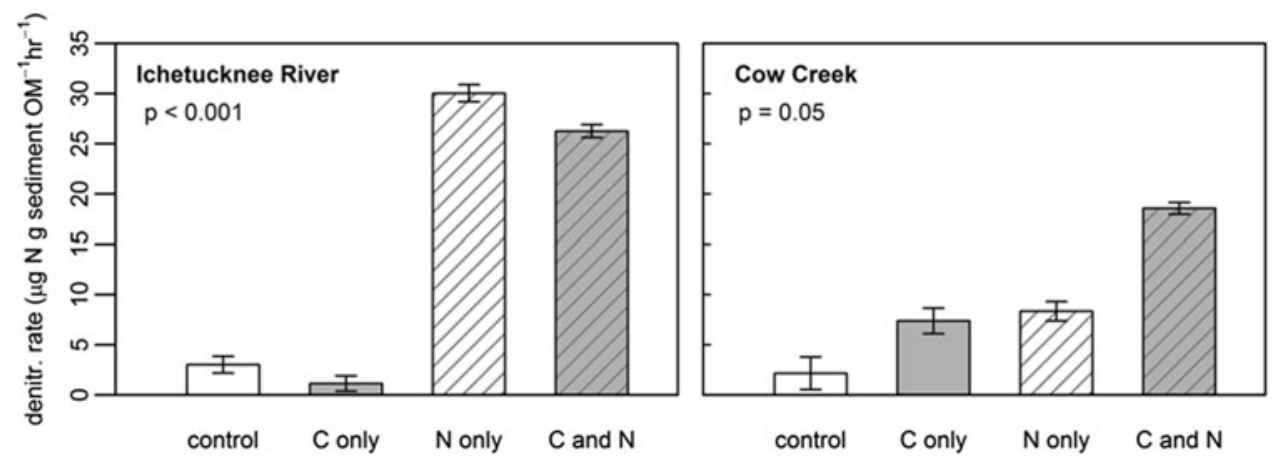

Figure 3. Responses to factorial C and N amendment in one spring (Ichetucknee River) and one blackwater (Cow Creek) site. Results from the spring-fed Ichetucknee River (left), show evidence of nitrate-only limitation of SOM-corrected denitrification rates, while results from the blackwater Cow Creek (right) show co-limitation of SOM-corrected denitrification rates by both nitrate and labile carbon. 
sediments, $P=0.53$; Figure 4$)$. Dosing with high concentrations of humic acid neither significantly depressed nor increased denitrification rates in any sediment type ( $P=0.84$; Figure 4$)$.

We observed a significant decrease in log-transformed potential denitrification rates (uncorrected for SOM content) along the $\mathrm{TOC}_{\mathrm{avg}}$ gradient $(P=0.03$; Figure 5$)$. However, because of the strong relationship between $\mathrm{TOC}_{\mathrm{avg}}$ and hydrologic variability, we also observed a strong negative relationship between denitrification rate and hydrologic variability $(P<0.001$; Figure 5$)$.

Regressions of SOM-corrected denitrification rate against $\mathrm{TOC}_{\mathrm{avg}}$ were not significant for any treatment (data not shown), nor did we find significant regressions between denitrification rate (in any treatment) and SRP. Although SRP also showed no significant relationship with RRs of treatment effects, RRs were significantly correlated with both $\mathrm{NO}_{3}{ }^{-}$avg and $\mathrm{TOC}_{\text {avg }}$ (Figure 6). $\mathrm{NO}_{3}{ }^{-}$avg explained $30 \%$ of the variation in $\mathrm{RR}_{\mathrm{N}: 0}$ $(P=0.02$; Figure $6 \mathrm{C})$. Similarly, the regression of $\mathrm{RR}_{\mathrm{CN}: \mathrm{C}}$ against $\mathrm{NO}_{3}{ }^{-}$avg was significant and negative $(P=0.04$; Figure $6 \mathrm{D})$. The relationship between $\mathrm{RR}_{\mathrm{C}: 0}$ and $\mathrm{TOC}_{\text {avg }}$ was not significant $(P=0.44)$; however, when one outlier was omitted, this relationship was significantly positive $(P=0.004)$, with $\mathrm{TOC}_{\text {avg }}$ explaining $40 \%$ of the variation in $\mathrm{RR}_{\mathrm{C}: 0}$ (Figure $6 \mathrm{~A}$ ). The relationship between $\mathrm{RR}_{\mathrm{CN}: \mathrm{N}}$ and $\mathrm{TOC}_{\mathrm{avg}}$ was positive, and described $44 \%$ of variation in $R_{\mathrm{CN}: \mathrm{N}}$ $(P=0.002$; Figure 6B).

\section{Discussion}

The dark-colored and high-molecular-weight DOC characteristic of Florida blackwater rivers neither stimulates [HO] nor directly inhibits denitrification [H2]. Denitrification rates did not increase in sediments incubated with BW or humic acid (Figure 4). In addition, the significant decline in ambient denitrification rates (rates measured in control treatment incubations) along the gradient of TOC $_{\text {avg }}$ (Figure 5) suggests that the elevated supply of DOC in the water column of blackwater rivers is not a labile $\mathrm{C}$ source for denitrifiers [Hl] and does not stimulate denitrification. Denitrification rates did not significantly decrease in sediments from spring or intermediate rivers incubated with water from BW sources and with high doses of humic acid under $\mathrm{N}$-replete or ambient $\mathrm{N}$ concentration conditions (Figure 4). Together, these results suggest that whereas the DOC in blackwater systems of Florida does not directly inhibit denitrification rates, this material has little metabolic benefit for denitrifying bacteria.

The decrease in denitrification rates over the TOC ${ }_{\text {avg }}$ gradient may be explained in part by lower availability of labile $\mathrm{C}$ in sites with higher long-term average TOC concentrations. We found direct evidence that denitrifiers are more likely to be $\mathrm{C}$ limited in high $\mathrm{TOC}_{\mathrm{avg}}$ sites [H3]. The response ratio of $\mathrm{C}$ amendment to control $\left(\mathrm{RR}_{\mathrm{C}: 0}\right)$ was positively related to $\mathrm{TOC}_{\mathrm{avg}}$ indicating greater severity of $\mathrm{C}$ limitation of denitrification

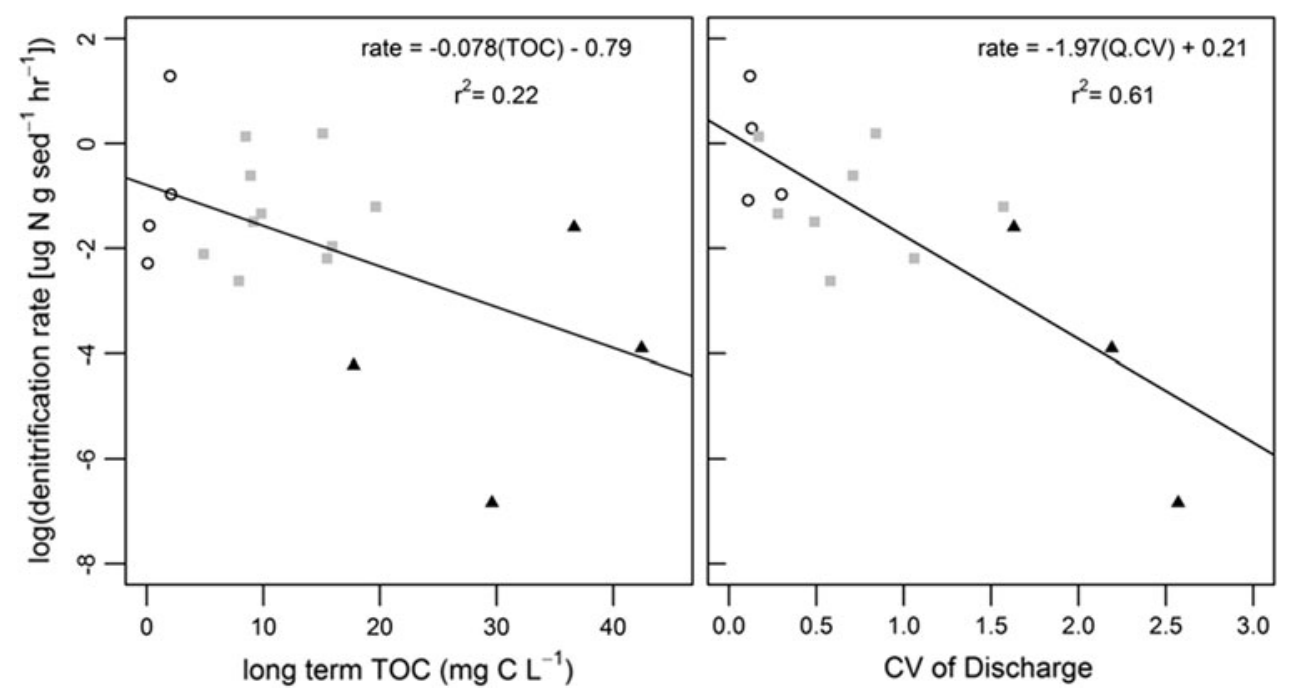

Fig. 5. Log-transformed denitrification rates versus $\mathrm{TOC}_{\mathrm{avg}}$ (left) and versus hydrologic variability $($ right $)$. Both $\mathrm{TOC}_{\mathrm{avg}}$ and hydrologic variability increase from springs (open circles), through intermediate systems (gray squares), to blackwater rivers (black triangles). Along both the $\mathrm{TOC}_{\mathrm{avg}}$ and hydrologic variability gradients, log-transformed denitrification rates decrease significantly $(P=0.03$ and $P<0.001$, respectively). 

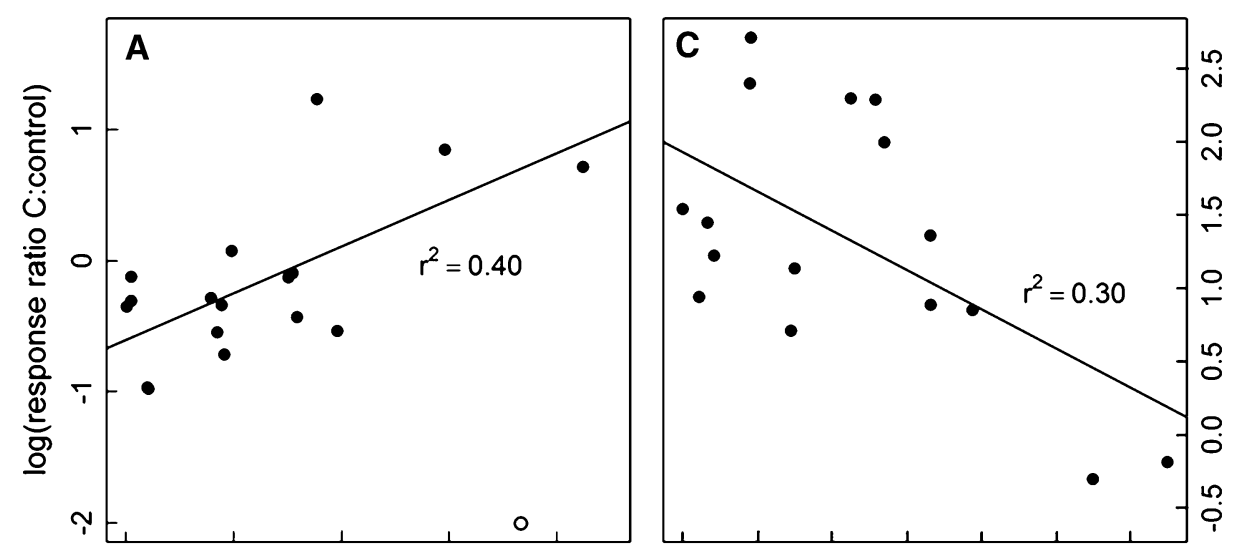

Fig. 6. RRs of treatment responses along springblackwater gradient. Long-term TOC was not significantly related to $\mathrm{C}$ :control ratio $(\mathbf{A}$ $P=0.44$, two negative values of RR removed), but when one outlier was removed (A open symbol), the relationship was significant and positive $\left(P=0.004, r^{2}=0.40\right)$. The $\mathrm{CN}: \mathrm{N}$ ratio was significantly positively correlated with long-term TOC (B $P=0.002)$, whereas long-term nitrate was significantly and negatively correlated to both $\mathrm{N}$ :control ratio $(\mathbf{C}$ $P=0.02)$ and $\mathrm{CN}: \mathrm{C}$ ratio (D $P=0.04$, two negative values of RR removed).

in systems with higher DOC concentrations. An increase in C limitation with increasing DOC is observed both in sediments that are subject to $\mathrm{N}$ limitation $\left(\mathrm{RR}_{\mathrm{C}: 0}\right)$ as well as those subjected to $\mathrm{N}$ replete conditions $\left(\mathrm{RR}_{\mathrm{CN}: \mathrm{N}}\right)$, meaning DOC-driven $\mathrm{C}$ limitation is independent of $\mathrm{NO}_{3}{ }^{-}$concentration. Increased severity of $\mathrm{C}$ limitation in blackwater as opposed to spring sites is also observed in the comparison of treatment effects between individual sites (Figure 3). In the Ichetucknee River, a spring site, the pattern of responses to treatments indicates $\mathrm{NO}_{3}{ }^{-}$-only limitation. In contrast, the pattern of denitrification treatment responses in sediments from Cow Creek, a blackwater site, suggests that the denitrifier community is co-limited by $\mathrm{NO}_{3}{ }^{-}$and labile C.

The most parsimonious explanation for this pattern is that the highly colored water limits aquatic primary production, reducing the availability of labile $\mathrm{C}$ and imposing energetic constraints on rates of denitrification. Because high water color, derived primarily from aromatic fulvic and humic acids, is associated with DOC from terrestrial sources as opposed to autochthonous production
(McKnight and others 1994), we conclude that the increase in DOC along the environmental gradient is driven by increased terrestrial DOC inputs (see also Duarte and others 2010). In addition to being less bioavailable (at least over short time scales; Koehler and others 2012), colored water decreases both UV and PAR penetration in the water column (Morris and others 1995; Williamson and others 1996; Phlips and others 2000). In the St. John's River, a blackwater river in northern Florida, Phlips and others observed a strong relationship between water color and vertical light attenuation (2000). Based on relationships between DOC and PAR attenuation in Adirondack lakes (Bukaveckas and Robbins-Forbes 2000), we roughly estimate how photic zone depth varies along our DOC gradient. Although the composition of the DOC pool likely differs between these lakes and the Florida rivers we studied, order-of-magnitude estimates show large differences in light penetration between spring and blackwater rivers. We estimate the mean depth of the photic zone in spring rivers exceeds $100 \mathrm{~m}$, whereas the mean depth of the photic zone in our blackwater river sites is $<1 \mathrm{~m}$. 
In rivers of the size we studied (most much deeper than $1 \mathrm{~m}$ ), the acute PAR attenuation in blackwater conditions is sufficient to exclude benthic primary production. A negative correlation between $\mathrm{TOC}_{\text {avg }}$ and $\triangle \mathrm{DO}$ (Appendix 1 in Supplementary material) further indicates that ecosystem primary production is limited in systems with high concentrations of DOC in the water column.

The conclusion that blackwater DOC inhibits denitrification rates indirectly through suppression of aquatic primary production is consistent with the inferences from high-frequency measurements of $\mathrm{NO}_{3}{ }^{-}$in the spring-fed Ichetucknee River. Heffernan and Cohen (2010) attributed $\sim 80 \%$ of total $\mathrm{N}$ removal in this system to denitrification. Much of the day-to-day variation in $\mathrm{N}$ removal ascribed to denitrification was explained by variation in gross primary production, which was, in turn, linked to changes in insolation. The most likely mechanism for coupling of primary production and $\mathrm{N}$ removal observed in their study is alleviation of C-limitation following days of high insolation as a result of increased exudation of labile DOC by primary producers (Heffernan and Cohen 2010). This withinsite relationship between productivity and denitrification implies that similar, and perhaps stronger, interactions may follow from variation in light across sites.

\section{Limitations of Experimental Approach}

Because denitrification incubations were conducted ex situ, the ambient and potential rates measured in these experiments may not be representative of actual rates in these systems. Removing sediments from rivers and transporting and homogenizing them before incubation exposes anoxic sediments to oxygen and destroys their structure. Removal of sediment for experimentation may also disrupt the effects of ongoing exudation by macrophyte and microphytobenthic communities. The approach used in this study, while useful for identifying limitations and potential rates of denitrification, also isolates sediments from any effects of flow. In natural river systems, advection continuously delivers $\mathrm{NO}_{3}{ }^{-}$and $\mathrm{C}$, but in our incubations, diffusion and hourly manual mixing were the only means of $\mathrm{NO}_{3}{ }^{-}$delivery to sediments during incubation. In addition, during transport and storage of water and sediment, labile DOC in the water column or in interstitial water of sediment samples may have been metabolized by organisms that passed through filtering of water or were collected with sediments. Finally, oxic conditions present at the beginning of denitrification incubation experiments could have led to competition between denitrifiers and aerobes for available $\mathrm{NO}_{3}^{-}$.

In many cases, however, the effects of these bottle experiment artefacts would be to mask rather than exaggerate expected treatment effects. Changes in $\mathrm{NO}_{3}{ }^{-}$availability and delivery in the incubations as compared to in situ conditions should manifest equally among sites, and should not impose a directional change in observed rates. If labile DOC were consumed during transport and storage of water and sediment, then the likelihood of $\mathrm{C}$ limitation should increase in sediments from sites with conditions that favored production of labile $\mathrm{C}$ by primary producers. Even given this possible masking effect of consumption of labile $\mathrm{C}$, we still observed a pattern of increasing $C$ limitation with increasing DOC. Competition between denitrifiers and aerobes during oxic periods of incubations, particularly in the C-only treatment, may explain the negative denitrification rates (that is, decreases in $\mathrm{N}_{2}$ concentration over the course of experiments) measured in several C-only treatment incubations, and should serve to mask differences in severity of $\mathrm{C}$ limitation along the DOC gradient of rivers rather than create false patterns.

Despite the possible limitations of these experiments, the ambient denitrification rates we observed show good agreement with both long-term and high-resolution mass balance estimates of denitrification in a spring river (Heffernan and Cohen 2010; Heffernan and others 2010). Heffernan and others (2010) used a mass balance approach to calculate areal denitrification rates of 23.8$32.1 \mathrm{mg} \mathrm{N} \mathrm{m}^{-2} \mathrm{~h}^{-1}$ for the spring-fed Ichetucknee River. Using a bulk density value of $1.21 \mathrm{~g} \mathrm{~cm}^{-3}$ for sediment of this river (R. Hensley, personal Communication.), we converted mass-based to areal rates, assuming an active denitrifying layer of depth $5 \mathrm{~cm}$ (Inwood and others 2007). Using the mean ambient denitrification rate for the Ichetucknee River of $0.378 \mu \mathrm{g} \mathrm{N} \mathrm{g} \mathrm{sed}^{-1} \mathrm{~h}^{-1}$ (Appendix 1 in Supplementary material), we calculated an areal rate of $22.9 \mathrm{mg} \mathrm{N} \mathrm{m}^{-2} \mathrm{~h}^{-1}$ - very similar to the mass-balance estimate. The areal denitrification rate measured for the Ichetucknee River also falls within the range of areal denitrification rates measured by the open-channel method, which uses MIMS to measure $\mathrm{N}_{2}$ production in situ over whole river reaches. Laursen and Seitzinger (2002) used the openchannel method to measure denitrification rates in three rivers in the U.S. and observed a wide range from 3.8 to $221.3 \mathrm{mg} \mathrm{N} \mathrm{m}^{-2} \mathrm{~h}^{-1}$.

The denitrification rates observed in this study also fall within the wide range reported from 
acetylene block measurements in other systems. The mean ambient rate for sediment incubations from all sites used in this study was $0.517 \mu \mathrm{g} \mathrm{N} \mathrm{g} \mathrm{sed}^{-1} \mathrm{~h}^{-1}$, very similar to the mean reported by Barnes and others (2012) of $0.696 \mu \mathrm{g} \mathrm{N} \mathrm{g} \mathrm{sed}^{-1} \mathrm{~h}^{-1}$ for Boulder Creek (Colorado, USA) and its tributaries. Arango and others (2007) report a range of ambient denitrification rates in Midwestern streams with varying benthic substrates from 0.1 to $11.1 \mu \mathrm{g} \mathrm{N} \mathrm{g} \mathrm{sed}{ }^{-1} \mathrm{~h}^{-1}$. Similarly, Groffman and others (2005) measured ambient denitrification rates in urban streams of Baltimore, MD, which ranged from $0.0026 \mu \mathrm{g} \mathrm{N}$ g sed $^{-1} \mathrm{~h}^{-1}$ in gravel-bed sediment to $4.96 \mu \mathrm{g} \mathrm{N}$ $\mathrm{g} \mathrm{sed}^{-1} \mathrm{~h}^{-1}$ in substrate from a debris dam. As in this study, Groffman and others (2005) found that denitrification rates were strongly correlated with SOM.

We have shown that denitrification rates are lower in Florida rivers with higher DOC concentrations, and have suggested a mechanism of increased Climitation resulting from light limitation of primary production. However, because of strong covariation between long-term TOC concentrations and hydrologic variability (Appendix 1 in Supplementary material) we cannot be confident in assigning an explanation of this pattern to either of these parameters. Either or both of these drivers could limit the abundance and productivity of aquatic vegetation, and thus inputs of labile $\mathrm{C}$, in blackwater rivers (Franklin and others 2008), and both potential drivers show strong negative relationships with denitrification rate (Figure 5). In these north Florida systems, some sites with relatively high hydrologic variability had established benthic vegetation communities (for example, sites on the Withlacoochee and Wekiva Rivers), suggesting that hydrologic variability alone is not sufficient to exclude submerged aquatic vegetation communities from Florida rivers. In sites with continuous flow data, we calculated the frequency of flood events greater than seven times the median annual flow, a metric correlated with disruption to macrophyte communities (Riis and Biggs 2003). Although blackwater sites had a higher frequency of these disrupting floods than spring systems (which did not exceed $7 \times$ median flow in any year over the 2000-2012 period of analysis), the highest frequency was still only 2.58 events year ${ }^{-1}$, a value corresponding to only minimal reduction $(<15 \%)$ of macrophyte abundance in a study by Riis and Biggs (2003).

Our inference that terrestrial DOC inhibits aquatic autotroph growth via reduced light is based on known effects of DOC on light availability in rivers and lakes (for example, Houser and others
2003; Julian and others 2008), and on low primary productivity commonly observed in blackwater systems (Meyer 1990; Carpenter and Pace 1997). Even in extremely oligotrophic lakes, light limitation by CDOM is the principle control on primary productivity (Karlsson and others 2009). Further evidence that DOC-mediated light-limitation can influence biogeochemical cycles comes from a lake in the northern U.S.A. West and others (2012) showed that terrestrial DOC stimulated methanogenesis in lake cores only slightly, whereas algal DOC fueled significant increases. Although it is likely that light limitation of photosynthesis by CDOM is an important constraint on vegetation abundance and thus labile $\mathrm{C}$ availability, future studies should address the influence of flow regime on macrophyte communities in Florida rivers.

The interface between macrophyte roots and sediments is a hotspot for denitrification. These sites provide superior conditions for denitrification because roots pump oxygen into the sediment, causing diel shifts in $\mathrm{O}_{2}$ concentration and redox conditions that favor diffusion of $\mathrm{NO}_{3}{ }^{-}$into the benthos and denitrification reactions (RisgaardPetersen and Jensen 1997; Ottosen and others 1999; Cohen and others 2012). In addition to the effects of $\mathrm{O}_{2}$ inputs, the labile $\mathrm{C}$ exuded by macrophyte roots can enhance denitrification rates by fueling the metabolism of denitrifying bacteria (Lin and others 2002; Heffernan and Cohen 2010). The exclusion of macrophyte communities (whether by DOC-induced light limitation or by removal because of hydrologic scour) can therefore limit denitrification by depriving microbes of ideal conditions and labile metabolic fuel.

\section{Conclusions: Light and Coupled C AND N in Aquatic Ecosystems}

Current understanding of $\mathrm{N}$ removal processes in rivers may be limited because most of the current methods involve scaling measurements made in small headwater streams to the channel geometry and hydrology of large rivers (Alexander and others 2000; Seitzinger and others 2002), thereby overlooking the important role of light in wider channels. This difference in light availability between large and small rivers leads to divergent effects on nutrient transformations, as well as distinct predictions about the effects of DOC on river biogeochemistry. The chemical effects of DOC on nutrient biogeochemistry may be similar, but the effects of DOC on the physical environment of streams leads to different predictions in aquatic systems which 
rely more heavily on light to fuel autochthonous production. Scaling measurements from small channels underestimates $\mathrm{N}$ removal in some large rivers because it de-emphasizes the importance of in situ OM production (for example, Heffernan and others 2010). The results of this study support the assertion made by Heffernan and others (2010) that scaling derived from hydrology and geometry alone, particularly in rivers with highly productive submerged aquatic vegetation communities, is insufficient to predict the magnitude of $\mathrm{N}$ removal in large rivers.

In large rivers and wetlands (especially those with clear water), autochthonous production is an important source of labile $\mathrm{C}$ for denitrifiers. Because understanding of $\mathrm{N}$ cycles in large rivers limits models of river network $\mathrm{N}$ dynamics (Wollheim and others 2006), clarifying the significance of denitrification in those lotic systems where light availability plays a large role in ecosystem metabolism will allow for more accurate global $\mathrm{N}$ budgets and predictions about the response of $\mathrm{C}$ and $\mathrm{N}$ cycles to altered nutrient and OM availability, hydrologic regimes, and other aspects of global change.

This study demonstrates that indirect effects of DOC on light may be as important as its direct role as a metabolite in shaping how $\mathrm{N}$ cycling responds to rising concentrations of DOC in surface waters. Because the quantity and quality of DOC in rivers are linked, the consequences of changing DOC will be multi-faceted (Prairie 2008). In Florida, blackwater rivers with high concentrations of DOC not only contain a high proportion of recalcitrant compounds, but the attenuation of light by CDOM also inhibits the production of more labile compounds produced by aquatic vegetation. Denitrification may, counterintuitively, become more C limited as concentrations of DOC increase in surface waters, diminishing the ability of freshwater ecosystems to remove reactive $\mathrm{N}$. This may have consequences not only for the ecology and biogeochemistry of those systems, but also for eutrophication of downstream ecosystems. DOC is the "great modulator" in aquatic ecosystems (Prairie 2008), and changes in its concentration and source will affect not only watershed and regional $\mathrm{C}$ balance (Cole and others 2007), but also biogeochemical cycles of elements coupled to $\mathrm{C}$.

\section{ACKNOWLEDGMENTS}

Thank you to Catherine Bravo, Kelsey Reider, Jenn Sweatman, Evan Rehm, Ewan Isherwood, Sean Koester, Anna Schnarnagl, Nate Lemoine, and Sabrina Jamil for help in the field, and to Ewan
Isherwood, Gabriel Sone, and Sean Koester for help in the lab. Yuying Zhang and Nate Lemoine helped with statistical analyses. Joe Boyer, Jim Fourqurean, Jennie Richards, Ewan Isherwood, and two anonymous reviewers gave valuable feedback on former versions of this manuscript. Comments from members of the Bernhardt and Heffernan labs as well as subject matter editor Dr. Stuart Bunn and two anonymous reviewers also helped improve the manuscript. We also thank the SERC Nutrient Analysis Laboratory for analyzing water samples, and Bill Anderson and Todd Kana for support with the MIMS. Permits for access to state and federal lands used as field sites were awarded by the Florida Department of Environmental Protection, U.S. Forest Service, and Florida Forest Service. We also offer special thanks to Ginger Morgan at Ichetucknee Springs State Park for logistical assistance with field work, and to Wekiva Island, King's Landing, and Canoe Outpost for providing boat ramp access and parking. This research was conducted under grants from Sigma Xi awarded to Megan Fork, and the National Science Foundation (EAR \#0838390) awarded to Dr. Jim Heffernan.

\section{REFERENCES}

Alexander RB, Smith RA, Schwarz GE. 2000. Effect of stream channel size on the delivery of nitrogen to the Gulf of Mexico. Nature 403:758-61.

Arango CP, Tank JL, Schaller JL, Royer TV, Bernot MJ, David MB. 2007. Benthic organic carbon influences denitrification in streams with high nitrate concentration. Freshw Biol 52:1210-22.

Barnes RT, Smith RL, Aiken GR. 2012. Linkages between denitrification and dissolved organic matter quality, Boulder Creek watershed, Colorado. J Geophys Res 117:G01014.

Bernhardt E, Likens G. 2002. Dissolved organic carbon enrichment alters nitrogen dynamics in a forest stream. Ecology 83:1689-700.

Bledsoe E, Phlips E. 2000. Relationships between phytoplankton standing crop and physical, chemical, and biological gradients in the Suwannee River and plume region, U.S.A. Estuar Coasts 23:458-73.

Bukaveckas P, Robbins-Forbes M. 2000. Role of dissolved organic carbon in the attenuation of photosynthetically active and ultraviolet radiation in Adirondack lakes. Freshw Biol 43:339-54.

Burgin AJ, Yang WH, Hamilton SK, Silver WL. 2011. Beyond carbon and nitrogen: how the microbial energy economy couples elemental cycles in diverse ecosystems. Front Ecol Environ 9:44-52.

Canfield DE, Glazer AN, Falkowski PG. 2010. The evolution and future of Earth's nitrogen cycle. Science 330:192-6.

Carpenter SR, Pace ML. 1997. Dystrophy and eutrophy in lake ecosystems: implications of fluctuating inputs. Oikos 78:3-14.

Cebrian J. 1999. Patterns in the fate of production in plant communities. Am Nat 154:449-68. 
Cohen MJ, Heffernan JB, Albertin A, Martin JB. 2012. Inference of riverine nitrogen processing from longitudinal and diel variation in dual nitrate isotopes. J Geophys Res Biogeosci 117:G01021.

Cole JJ, Carpenter SR, Pace ML, Van de Bogert MC, Kitchell JL, Hodgson JR. 2006. Differential support of lake food webs by three types of terrestrial organic carbon. Ecol Lett 9:558-68.

Cole JJ, Prairie YT, Caraco NF, McDowell WH, Tranvik LJ, Striegl RG, Duarte CM, Kortelainen P, Downing JA, Middelburg JJ, Melack J. 2007. Plumbing the global carbon cycle: integrating inland waters into the terrestrial carbon budget. Ecosystems 10:171-84.

Dodla SK, Wang JJ, DeLaune RD, Cook RL. 2008. Denitrification potential and its relation to organic carbon quality in three coastal wetland soils. Sci Total Environ 407:471-80.

Duarte CM, Prairie YT, Frazer TK, Hoyer MV, Notestein SK, Martinez R, Dorsett A, Canfield DE. 2010. Rapid accretion of dissolved organic carbon in the springs of Florida: the most organic-poor natural waters. Biogeosciences 7:4051-7.

Ensign SH, Doyle MW. 2006. Nutrient spiraling in streams and river networks. J Geophys Res 111:G04009.

Evans CD, Monteith DT, Cooper DM. 2005. Long-term increases in surface water dissolved organic carbon: observations, possible causes and environmental impacts. Environ Pollut 137:55-71.

Eyre BD, Rysgaard S, Dalsgaard T, Christensen PB. 2002. Comparison of isotope pairing and N2:Ar methods for measuring sediment denitrification-assumptions, modifications, and implications. Estuaries 25:1077-87.

Franklin P, Dunbar M, Whitehead P. 2008. Flow controls on lowland river macrophytes: a review. Sci Total Environ 400:369-78

Freeman C, Evans C, Monteith D, Reynolds B, Fenner N. 2001. Export of organic carbon from peat soils. Nature 412:785.

Galloway JN, Aber JD, Erisman JW, Seitzinger SP, Howarth RW, Cowling EB, Cosby BJ. 2003. The nitrogen cascade. BioScience 53:341-56.

Groffman PM, Altabet MA, Bohlke JK, Butterbach-Bahl K, David MB, Firestone MK, Giblin AE, Kana TM, Nielsen LP, Voytek MA. 2006. Methods for measuring denitrification: diverse approaches to a difficult problem. Ecol Appl 16:2091-122.

Hamme RC, Emerson SR. 2004. The solubility of neon, nitrogen and argon in distilled water and seawater. Deep-Sea Res I 51:1517-28.

Heffernan JB, Cohen MJ, Frazer TK, Thomas RG, Rayfield TJ, Gulley J, Martin JB, Delfino JJ, Graham WD. 2010. Hydrologic and biotic influences on nitrate removal in a subtropical spring-fed river. Limnol Oceanogr 55:249-63.

Heffernan JB, Cohen MJ. 2010. Direct and indirect coupling of primary production and diel nitrate dynamics in a subtropical spring-fed river. Limnol Oceanogr 55:677-88.

Heffernan JB, Albertin AR, Fork ML, Katz BG, Cohen MJ. 2012. Denitrification and inference of nitrogen sources in the karstic Floridan aquifer. Biogeosciences 9:1671-90.

Heffernan JB, Fisher SG. 2012. Plant-microbe interactions and nitrogen dynamics during wetland establishment in a desert stream. Biogeochemistry 107:379-91.

Herrman K, Bouchard V, Moore R. 2008. Factors affecting denitrification in agricultural headwater streams in Northeast Ohio, USA. Hydrobiologia 598:305-14.

Houser JN, Bade DL, Cole JJ, Pace ML. 2003. The dual influences of dissolved organic carbon on hypolimnetic metabolism: or- ganic substrate and photosynthetic reduction. Biogeochemistry 64:247-69.

Hruška J, Krám P, McDowell WH, Oulehle F. 2009. Increased dissolved organic carbon (DOC) in Central European streams is driven by reductions in ionic strength rather than climate change or decreasing acidity. Environ Sci Technol 43:4320-6.

Inwood SE, Tank JL, Bernot MJ. 2007. Factors controlling sediment denitrification in midwestern streams of varying land use. Microb Ecol 53:247-58.

Julian JP, Doyle MW, Powers SM, Stanley EH, Riggsbee JA. 2008. Optical water quality in rivers. Water Resour Res 44:W10411.

Kana TM, Darkangelo C, Hunt MD, Oldham JB, Bennett GE, Cornwell JC. 1994. Membrane inlet mass-spectrometer for rapid high-precision determination of $\mathrm{N}_{2}, \mathrm{O}_{2}$, and $\mathrm{Ar}$ in environmental water samples. Anal Chem 66:4166-70.

Karlsson J, Byström P, Ask J, Ask P, Persson L, Jansson M. 2009. Light limitation of nutrient-poor lake ecosystems. Nature 460:506-9.

Koehler B, von Wachenfeldt E, Kothawala D, Tranvik LJ. 2012. Reactivity continuum of dissolved organic carbon decomposition in lake water. J Geophys Res 117:G01024.

Lamberti GA, Steinman AD. 1997. A comparison of primary production in stream ecosystems. J N Am Benthol Soc 16:95104.

Laursen AE, Seitzinger SP. 2002. Measurement of denitrification in rivers: an integrated, whole reach approach. Hydrobiologia 485:67-81.

Lin Y-F, Jing S-R, Wang T-W, Lee D-Y. 2002. Effects of macrophytes and external carbon sources on nitrate removal from groundwater in constructed wetlands. Environ Pollut 119:413-20.

McDowell WH, Likens GE. 1988. Origin, composition, and flux of dissolved organic-carbon in the Hubbard Brook Valley. Ecol Monogr 58:177-95.

McKnight D, Andrews E, Spaulding S, Aiken G. 1994. Aquatic fulvic-acids in algal-rich Antarctic ponds. Limnol Oceanogr 39:1972-9.

McKnight DM, Bencala KE. 1990. The chemistry of iron, aluminum and dissolved organic material in 3 acidic, metal-enriched mountain streams, as controlled by watershed and instream processes. Water Resour Res 26:3087-100.

Meyer JL. 1990. A blackwater perspective on riverine ecosystems. Bioscience 40:643-51.

Moran M, Zepp R. 1997. Role of photoreactions in the formation of biologically labile compounds from dissolved organic matter. Limnol Oceanogr 42:1307-16.

Morris DP, Zagarese H, Williamson CE, Balseiro EG, Hargreaves BR, Modenutti B, Moeller R, Queimalinos C. 1995. The attenuation of solar UV radiation in lakes and the role of dissolved organic carbon. Limnol Oceanogr 40:1381-91.

Mulholland PJ, Helton AM, Poole GC, Hall RO Jr, Hamilton SK, Peterson BJ, Tank JL, Ashkenas LR, Cooper LW, Dahm CN, Dodds WK, Dodds WK, Findlay SEG, Gregory SV, Grimm NB, Johnson SL, McDowell WH, Meyer JL, Valett HM, Webster JR, Arango CP, Beaulieu JJ, Bernot MJ, Burgin AJ, Crenshaw CL, Johnson LT, Niederlehner BR, O'Brien JM, Potter JD, Sheibley RW, Sobota DJ, Thomas SM. 2008. Stream denitrification across biomes and its response to anthropogenic nitrate loading. Nature 452:202-7.

Mulholland PJ, Houser JN, Maloney KO. 2005. Stream diurnal dissolved oxygen profiles as indicators of in-stream metabo- 
lism and disturbance effects: Fort Benning as a case study. Ecol Indic 5:243-52.

Mulholland PJ. 1997. Dissolved organic matter concentration and flux in streams. J N Am Benthol Soc 16:131-41.

Münster U, De Haan H. 1998. The role of microbial extracellular enzymes in the transformation of dissolved organic matter in humic waters. In: Hessen DO, Tranvik LJ, Eds. Aquatic humic substances. Berlin: Springer. p 199-257.

Myers RL, Ewel JJ, Eds. 1990. Ecosystems of Florida. Orlando (FL): First University Press of Florida. 765 p.

Ottosen L, Risgaard-Petersen N, Nielsen L. 1999. Direct and indirect measurements of nitrification and denitrification in the rhizosphere of aquatic macrophytes. Aquat Microb Ecol 19:81-91.

Odum HT. 1957a. Trophic structure and productivity of Silver Springs, Florida. Ecol Monogr 27:55-112.

Odum HT. 1957b. Primary production measurements in eleven Florida springs and a marine turtle-grass community. Limnol Oceanogr 2:85-97.

Peterson BJ, Wollheim WM, Mulholland PJ, Webster JR, Meyer JL, Tank JL, Marti E, Bowden WB, Valett HM, Hershey AE, McDowell WH, Dodds WK, Hamilton SK, Gregory S, Morrall DD. 2001. Control of nitrogen export from watersheds by headwater streams. Science 292:86-90.

Pfenning KS, McMahon PB. 1997. Effect of nitrate, organic carbon, and temperature on potential denitrification rates in nitrate-rich riverbed sediments. J Hydrol 187:283-95.

Phlips EJ, Cichra M, Aldridge FJ, Jembeck J, Hendrickson J, Brody R. 2000. Light availability and variations in phytoplankton standing crops in a nutrient-rich backwater river. Limnol Oceanogr 45:916-29.

Piña-Ochoa E, Álvarez-Cobelas M. 2006. Denitrification in aquatic environments: a cross-system analysis. Biogeochemistry 81:111-30.

Prairie YT. 2008. Carbocentric limnology: looking back, looking forward. Can J Fish Aquat Sci 65:543-8.

R Development Core Team. 2012. R: A language and environment for statistical computing. Vienna, Austria: R Foundation for Statistical Computing http://www.r-project.org/. Accessed 30 Mar 2013.

Riis T, Biggs BJF. 2003. Hydrologic and hydraulic control of macrophyte establishment and performance in streams. Limnol Oceanogr 48:1488-97.

Risgaard-Petersen N, Jensen K. 1997. Nitrification and denitrification in the rhizosphere of the aquatic macrophyte Lobelia dortmanna L. Limnol Oceanogr 42:529-37.

Roulet N, Moore TR. 2006. Environmental chemistry: browning the waters. Nature 444:283-4.

Sabater F, Meyer J, Edwards R. 1993. Longitudinal patterns of dissolved organic carbon concentration and suspended bacterial density along a blackwater river. Biogeochemistry 21:73-93.

Schlesinger WH, Cole JJ, Finzi AC, Holland EA. 2011. Introduction to coupled biogeochemical cycles. Front Ecol Environ 9:5-8.

Scott TM, Means GH, Meegan RP, Means RC, Upchurch SB, Copeland JJ, Roberts T, Willet A. 2004. Bulletin No. 66: Springs of Florida. Florida Geological Survey.
Seitzinger S, Harrison JA, Böhlke JK, Bouwman AF, Lowrance R, Peterson B, Tobias C, Drecht GV. 2006. Denitrification across landscapes and waterscapes: a synthesis. Ecol Appl 16:2064-90.

Seitzinger SP, Styles RV, Boyer EW, Alexander RB, Billen G, Howarth RW, Mayer B, Breemen N. 2002. Nitrogen retention in rivers: model development and application to watersheds in the northeastern U.S.A. Biogeochemistry 57-58:199-237.

Sierra M, Donard O, Lamotte M. 1997. Spectral identification and behaviour of dissolved organic fluorescent material during estuarine mixing processes. Mar Chem 58:51-8.

Stedmon C, Markager S, Bro R. 2003. Tracing dissolved organic matter in aquatic environments using a new approach to fluorescence spectroscopy. Mar Chem 82:239-54.

Sterner RW, Elser JJ. 2002. Ecological stoichiometry: the biology of elements from molecules to the biosphere. Princeton (NJ): Princeton University Press. p 439.

Sun L, Perdue EM, Meyer JL, Weis J. 1997. Use of elemental composition to predict bioavailability of dissolved organic matter in a Georgia river. Limnol Oceanogr 42:714-21.

Tank JL, Rosi-Marshall E, Baker MA, Hall RO. 2008. Are rivers just big streams? A pulse method to quantify nitrogen demand in a large river. Ecology 89:2935-45.

Taylor PG, Townsend AR. 2010. Stoichiometric control of organic carbon-nitrate relationships from soils to the sea. Nature 464:1178-81.

Thorp JH, Delong MD. 2002. Dominance of autochthonous autotrophic carbon in food webs of heterotrophic rivers. Oikos 96:543-50

Turner RE, Rabalais NN. 1991. Changes in Mississippi River water quality this century. BioScience 41:140-7.

Vadeboncoeur Y, Jeppesen E, Vander Zanden MJ, Schierup H-H, Christoffersen K, Lodge DM. 2003. From Greenland to green lakes: cultural eutrophication and the loss of benthic pathways in lakes. Limnol Oceanogr 48:1408-18.

Vannote RL, Minshall GW, Cummins KW, Sedell JR, Cushing CE. 1980. The river continuum concept. Can J Fish Aquat Sci 37:130-7.

Venables WN, Ripley BD. 2002. Modern Applied Statistics with S. New York: Springer. p 497.

Vitousek PM, Aber JD, Howarth RW, Likens GE, Matson PA, Schindler DW, Schlesinger WH, Tilman DG. 1997. Human alteration of the global nitrogen cycle: sources and consequences. Ecol Appl 7:737-50.

West WE, Coloso JJ, Jones SE. 2012. Effects of algal and terrestrial carbon on methane production rates and methanogen community structure in a temperate lake sediment. Freshw Biol 57:949-55.

Williamson CE, Stemberger RS, Morris DP, Frost TM, Paulsen SG. 1996. Ultraviolet radiation in North American lakes: attenuation estimates from DOC measurements and implications for plankton communities. Limnol Oceanogr 41:1024-34.

Wollheim WM, Vörösmarty CJ, Peterson BJ, Seitzinger SP, Hopkinson CS. 2006. Relationship between river size and nutrient removal. Geophys Res Lett 33:L06410.

Worrall F, Burt T, Adamson J. 2004. Can climate change explain increases in DOC flux from upland peat catchments? Sci Total Environ 326:95-112. 